\title{
Effects of cold water immersion on variables of balance in healthy subjects with open and closed eyes
}

\author{
Efeito da crioimersão nas variáveis de equilíbrio em \\ indivíduos saudáveis com olhos abertos e fechados
}

\author{
Simone Sayomi Tano ${ }^{[a]}$, Karen Barros Parron Fernandes ${ }^{[a]}$, \\ Auristela Duarte Lima Moser ${ }^{[b]}$, Deise Aparecida de Almeida Pires-Oliveira ${ }^{[a]}$, \\ Andre Wilson Oliveira Gil ${ }^{[a]}$, Rodrigo Franco de Oliveira ${ }^{[a] *}$ \\ [a] Universidade Norte do Paraná (Unopar), Londrina, PR, Brazil \\ [b] Pontifícia Universidade Católica do Paraná, Curitiba, PR, Brazil
}

\begin{abstract}
Introduction: Cryotherapy is the use of cold as therapeutic approach. Although often used, its impact on the postural balance is not well-known. Objectives: To analyze the effects of cold water immersion in the postural balance on single-leg balance in healthy subjects through the variables of center-of-pressure, velocity anteroposterior and medial-lateral oscillations, comparing conditions open and closed eyes in the moments before, immediately, 20 and 40 minutes after cold water immersion. Material and methods: Cross-sectional study with 30 male subjects, cold water immersion at $5{ }^{\circ} \mathrm{C}$ during 15 minutes assessed in a force platform, protocol of 3 trials of 30 seconds each with 10 seconds of rest, the average of the 3 trials
\end{abstract}

* SST: MSc, e-mail: simonetano@gmail.com KBPF: PhD, e-mail: karenparron@yahoo.com.br ADLM: PhD, e-mail: auristela.lima@gmail.com DAAPO: PhD, e-mail: deisepyres@yahoo.com.br AWOG: MSc, e-mail: andre_gil17@hotmail.com RFO: PhD, e-mail: rfrancoli@yahoo.com.br 
was used for analysis. The software GraphPad Prisma 5.0 was used for statistical analysis, with the ANOVA test for repeated measures and comparisons with test of Friedman and post-test of Dunn. Results: It was observed improvement of the balance by the results of the following variables: in the condition Open Eyes (OE) it was observed significant difference only in the velocity anteroposterior (AP) in the moment before immersion when compared to the 40-minute moment. Significant differences were observed in the condition Closed Eyes (CE) in the following comparisons: in the Center-of-Pressure (COP) only at the immediate moment when compared to the 40-minute moment; in the velocity AP in the moment before when compared to the 40-minute moment, in the immediate moment when compared to the 20-minute and 40-minute moments; and in the medial-lateral velocity (Vel-ML) in two comparisons: in the moment before immersion when compared to the 20-minute and 40-minute moments after cryotherapy. Results show safety in performing activities after cryotherapy. Conclusion: Improvement of the postural balance after cold water immersion on the predetermined conditions of this study.

Keywords: Cryotherapy. Postural balance. Balance.

\section{Resumo}

Introdução: A crioterapia consiste na utilização local do frio como abordagem terapêutica. Embora frequentemente utilizada, seu impacto no equilíbrio corporal é pouco explorado. Objetivos: Analisar a influência da crioimersão no equilíbrio estático em apoio unipodal em indivíduos saudáveis por meio de variáveis do centro de pressão, oscilações da velocidade anteroposterior e médio-lateral, comparando condições olhos abertos e fechados nos momentos prévios, imediatamente, 20 e 40 minutos após crioimersão. Materiais e métodos: Estudo transversal realizado com 30 sujeitos do gênero masculino: crioimersão a $5{ }^{\circ} \mathrm{C}$ durante 15 minutos; avaliação na plataforma de força, protocolo de 3 tentativas de 30 segundos cada, com 10 segundos de descanso; média das 3 medidas foi adotada para análise. Utilizou-se o programa GraphPad Prisma 5.0, ANOVA de medidas repetidas e comparações com teste de Friedman e pós-teste de Dunn. Resultados: Verificou-se melhora do equilíbrio por meio dos resultados das seguintes variáveis analisadas: na condição Olhos Abertos $(O A)$ observou-se diferença significativa apenas na velocidade anteroposterior (Vel-AP) no tempo pré-imersão comparado com 40 minutos. Com Olhos Fechados (OF) observou-se diferenças significativas nas seguintes comparações: no Centro-de-Pressão (COP) apenas no momento imediato comparado com 40 minutos; na velocidade AP no momento pré-comparado com o tempo de 40 minutos e no momento imediato comparado com 20 e 40 minutos após; e na velocidade médio-lateral (Vel-ML) no tempo pré-imersão comparado com 20 e 40 minutos após. Os resultados demonstram segurança na realização de atividades após crioterapia. Conclusão: Verificou-se melhora do equilíbrio postural após crioimersão nas condições predeterminadas neste estudo.

Palavras-chave: Crioterapia. Equilíbrio postural. Equilíbrio.

\section{Introduction}

Cryotherapy consists of using cold location as a therapeutic approach $(1,2,3)$; contributing to reduce pain, tissue temperature, metabolism, edema, circulation, muscle spasm, it also may cause decrease in venous flow, affecting the articular function. It is one of the most commonly used treatment method applied in conditions of acute soft tissue injuries $(4,5)$.
In sports, it is frequently used in acute musculoskeletal lesions with the objective of bringing a fast comeback of the athlete to their sport activities, considering that its effects and applicability in body segments such as knees and ankles, frequent target of lesions, have been widely studied $(6,7)$.

The use of cryotherapy in sports practice and in rehabilitation centers has been considered as a popular method of treatment for acute and chronic lesions (8). Some authors report about the different types of 
cryotherapy application, its capacity of reducing the tissue temperature, decrease of nerve conduction speed and also report about its influence in postural balance $(7,9,10)$.

The modality, the time of application and the cooling time, may cause negative effects due to the decrease of conduction speed of afferent fibers (11). This, alters both the sense of articular perception and the decrease of functional performance, with the possibility of causing undesired effects in articular stability and postural balance alterations (12), compromising the sport performance, favoring the occurrence of lesions when athletes resume their activities right after ice application $(13,14$, 15). Although cooling may bring bigger tolerance to motor activities through sedation, the increase of postural oscillation may occur due to the decrease of proprioception $(16,17)$.

Proprioception is the mechanism of body perception in which the peripheral receptors send information to Central Nervous System (CNS) relating the body movements to the position sense (18).

Posture control is built up by a set of assembled segments, each with its own mass, that are linked together by flexible joints controlled by the neuromuscular system and involves interactions between external and internal strengths (19) making use of balance strategies, being the main strategies used in static posture, the hip and ankle strategies (20). It is possible to observe that the postural balance also may be affected by the use of cryotherapy, and researchers recommend $(12,21)$ prudence in immediate return situations to activities after cryotherapy.

Even though it is widely used in clinical practice and sport, there is no certainty about the impact of its effects on postural balance, not even if its application may bring lesion risks. Besides, it also occurs the lack of a statement in relation to the safe time of recovering to resume physical activities.

In face of these facts, the present study has as an objective to analyze the influence of cold water immersion in the static balance in single-leg stance in healthy young people, through the area of center-ofpressure, oscillations of anteroposterior velocity (VelAP) and medial-lateral (Vel-ML) variables, comparing open eyes (OE) and closed eyes (CE) conditions in before moment, immediately, 20 and 40 minutes after cold water immersion.

\section{Materials and methods}

\section{Ethical procedures}

The study was realized at the Research Center in Health Studies of University Norte do Paraná (Unopar) in the Human Motor Performance and Functional Evaluation (LAHUF) laboratory after the Ethic and Research Committee (CEP) consent, under record number 276.702. All the research processes followed the ethical principles in the Resolution number 466/2012 from National Health Council, from Ministry of Health, guaranteeing to the participants, among other rights, the inform consent form, privacy and safe keeping of information.

\section{Design and population of study}

It is a cross-sectional study. Healthy individuals between 18 and 35 years old were included, male gender, no history of musculoskeletal injuries in the last six months and that were not professional athletes. Subjects were excluded with Body Mass Index (BMI) bigger then 30, with allergy to cold, dermatitis in the area of ankles and feet, with the presence of lesions, injuries or skin rashes in the area of ankles and feet, visual or vestibular impaired relevant and advanced diabetes.

It was used the sample size calculation in the program PASS 12.0, using as parameters the data obtained in the study of Kernozek et al. (17), which observed difference in cold water immersion in relation to balance parameters $(\mathrm{F}=36.78$ and $\mathrm{p}=0.001)$. Considering these data in conjunction with the confidence interval of $95 \%$, alpha level of $5 \%$ and power test of $80 \%$, it was determined that the minimum sample of this study was 28 individuals. Considering possible losses during the evaluation, 30 individuals were recruited.

\section{Data collection}

The subjects were analyzed in the period between May and July 2013, realized always in the same period of the day in predetermined date and time, respecting a rest period of 15 minutes, on a conventional chair 
(with no footwear, nor socks) before the beginning of collection; all the experimental procedures were realized always by the same evaluators.

The temperature measuring of the ankle was verified in an area of about five millimeters below the most protuberant point of the lateral malleolus where the laser pointer Incoterm $^{\mathrm{TM}}$ output $<1 \mathrm{~mW}$, Wavelength 630-670 $\mathrm{mm}$ ) was positioned perpendicularly to the area, about five centimeters of distance from the skin.

For cold water immersion procedures it was used a plastic recipient (oval bucket), capacity of 12 liters, containing 6 liters of water with the room at environment temperature being introduced cubed ice. The temperature of cooled water was kept in a medium temperature of $5^{\circ} \mathrm{C}$, verified by the laser thermometer (above mentioned) being constantly verified, this way it was added ice for the temperature maintenance when necessary, with the individual sat with the angle of hip and knee close to 90 degrees with immersion of the lower limb preference completely covering the foot in contact with the bucket, with a water blade of 10 centimeters above the lateral malleolus during 15 minutes. Just one member (preference member) was evaluated in this group, it being subjected to cold water immersion and it was used to assess balance measurements on the force platform. For the count the time it was used a chronometer (Casio Hs-3 Digital Professional Lap Split Wr), and the environment temperature was verified by an acrylic room thermometer (Incoterm, ecological filling [TAI 12.3014]).

To evaluate postural balance it was used the force platform Biomec400 produced in Brazil by EMG system of Brazil, validated by da Silva et al. (22), which is able to quantify the distribution of vertical force in four points, its size is $500 \times 500 \times 100$ $\mathrm{mm}$. Considered gold-standard instrument (23), the reaction of the platform signals, after filtered, are analyzed by routines from the program MatLab with their own software which extracts the main parameters of postural balance (22).

The data collection was realized in controlled environment with an acclimatized room (mean temperature of $27{ }^{\circ} \mathrm{C}$ ) where the individuals were familiarized with the equipment and the experimental protocol. For the Postural Balance (PB), the individuals were oriented to remain in single-leg stance (lower limb preference) on the force platform (22), with no footwear nor socks, loose arms and relaxed along the body and with cephalic segment positioned vertically to the ground plan. The test was initially realized, from the experimental protocol, $\mathrm{OE}$, asking participants to watch a target (black cross $=14.5 \mathrm{~cm} \mathrm{x}$ $14.5 \mathrm{~cm} \mathrm{x} 4 \mathrm{~cm}$ ) fixed on a white wall, at the same height of the eyes with frontal distance of 2 meters from their eyes. Next, the individuals were oriented to realize the test with CE. Three attempts of $30 \mathrm{sec}-$ onds with 10 seconds of rest were realized and the average of the three trials was used for analysis (24).

The measurements of static balance and skin temperature were measured in four moments: 1 ) in condition of before immersion; 2) immediately after immersion; 3) 20 minutes; and 4) 40 minutes after cold water immersion. The evaluated parameters were COP, Vel-AP, and Vel-ML.

\section{Statistical analysis}

The entire statistic procedures were realized through the software GraphPad Prism 5.0, being established a confidence interval of $95 \%$ and significance level of $5 \%$ for the applied tests $(\mathrm{p}<0.05)$. It was used the Shapiro-Wilk test to analyze the distribution of data. Considering that the variables of balance did not present normal distribution, the data were presented in median and interquartile ranges [25-75\%]. The comparisons were verified using the Friedman test with post-test of Dunn. The anthropometric data presented normal distribution; therefore, they were presented as average and standard deviation.

\section{Results}

Participated in this research, 30 individuals of male gender, aged between 18 and 33 years old (age average: $22.93( \pm 4.63)$, weight: $76.42 \mathrm{~kg}( \pm 10,43)$, height: $1.78 \mathrm{~cm}( \pm 0.07)$ and BMI $23.49 \mathrm{~kg} / \mathrm{m}^{2}$ ( \pm 2.96$)$ ).

Among the individuals, 25 adopted the right lower limb as the preference member, and 5 adopted the left lower limb.

The average temperature of the cooling water used for immersion was $5.27{ }^{\circ} \mathrm{C}( \pm 0.05)$ while the room temperature was $27,73^{\circ} \mathrm{C}( \pm 1.08)$.

The average values of superficial temperature of the ankle presented by the population of study in 
the moment of before cold water immersion were $30.69^{\circ} \mathrm{C}( \pm 1.60)$. Immediately after cryotherapy the temperature was reduced to $12.93 \stackrel{\circ}{\circ}( \pm 1.48)$. In the period of 20 and 40 minutes after cryotherapy it was observed a tendency to reheating presenting an average of $23.47^{\circ} \mathrm{C}( \pm 2.22)$ and $25.76{ }^{\circ} \mathrm{C}$ $( \pm 2.17)$ respectively. Differences on the surface temperature of the ankle skin in the lateral region were observed in different experimental periods (before immersion, immediately after immersion, 20 and 40 minutes post immersion).

Analysis of variables of single-leg balance with open eyes

Differences were observed in the AP direction speed during pre-immersion period compared to speed after 40 minutes (Friedman's test, post-test of Dunn, p $<0.05$, Table 1 and Figure 2). However, statistically significant differences were not observed to COP (Friedman's test, post-test of Dunn, $p=0.22$, Table 1 and Figure 1), and not even for medial-lateral velocity direction (Friedman's test, post-test of Dunn, $p=0.07$, Table 1 and Figure 3).

Analysis of variables of single-leg balance with closed eyes

The single-leg balance data in CE condition showed statistically significant differences indicating an improvement in balance for the following conditions: for COP in immediate period compared to the area after 40 minutes (Friedman's test, post-test of Dunn, $\mathrm{p}<0.05$, Table 2 and Figure 1), for AP velocity in pre-immersion velocity period compared to 40 minutes and the immediate period compared to 20 and 40 minutes (Friedman's test, post-test of Dunn, $\mathrm{p}=0.0008$, Table 2 and Figure 2); for medial-lateral velocity in the period of pre-immersion compared to the speed 20 minutes and also 40 minutes after cold water immersion (Friedman's test, post-test of Dunn, $p=0.0008$, Table 2 and Figure 3). For other comparisons, there were not statistically significant differences.

Table 1 - Descriptive values of the parameters of single-leg balance - open eyes

\begin{tabular}{cccccc}
\hline & \multicolumn{2}{c}{ Single-leg balance - Open Eyes - Median [25-75\%] } & & \\
\cline { 2 - 6 } Variables & Pre & Immed. & 20 min. & 40 min. & p value \\
\hline COP $\left(\mathbf{c m}^{2}\right)$ & $8.1[7.1-9.6]^{\mathrm{a}}$ & $9.2[7.6-11.8]^{\mathrm{a}}$ & $8.5[7.1-10.9]^{\mathrm{a}}$ & $7.9[6.8-9.8]^{\mathrm{a}}$ & 0.22 \\
Vel-AP (cm/s) & $2.6[2.3-3.0]^{\mathrm{a}}$ & $2.4[2.1-2.8]^{\mathrm{a}, \mathrm{b}}$ & $2.3[2.2-2.7]^{\mathrm{a}, \mathrm{b}}$ & $2.3[2.1-2.7]^{\mathrm{b}}$ & 0.02 \\
Vel-ML (cm/s) & $2.5[2.3-2.9]^{\mathrm{a}}$ & $2.3[2.1-2.9]^{\mathrm{a}}$ & $2.5[2.1-2.8]^{\mathrm{a}}$ & $2.4[2.1-2.7]^{\mathrm{a}}$ & 0.07 \\
\hline
\end{tabular}

Note: Pre = before immersion; Immed. = immediately after immersion; 20 min. = 20 minutes after immersion; 40 min. = 40 minutes after immersion; COP = center-of-pressure; Vel-AP = anteroposterior velocity; Vel-ML = medial-lateral velocity. Different letters represent different groups (Friedman's test, Post-test of Dunn).

Table 2 - Descriptive values of the parameters of single-leg balance - closed eyes

\begin{tabular}{cccccc}
\hline & \multicolumn{2}{c}{ Single-leg balance - Closed eyes - Median [25-75\%] } \\
\cline { 2 - 6 } Variables & Pre & Immed. & 20 min. & 40 min. & p value \\
\hline COP (cm $)$ & $26.6[20.5-31.2]^{\mathrm{a}}$ & $28.9[24.1-36.6]^{\mathrm{a}, \mathrm{b}}$ & $28.1[20.8-32.8]^{\mathrm{a}, \mathrm{b}}$ & $22.9[18.3-30.2]^{\mathrm{b}}$ & 0.0005 \\
Vel-AP (cm/s) & $5.7[4.7-7.1]^{\mathrm{a}}$ & $6.3[5.3-7.3]^{\mathrm{a}, \mathrm{c}}$ & $5.4[4.7-6.5]^{\mathrm{a}, \mathrm{d}}$ & $5.1[4.3-6.1]^{\mathrm{b}, \mathrm{d}}$ & 0.0008 \\
Vel-ML (cm/s) & $5.6[5.0-6.6]^{\mathrm{a}}$ & $5.4[4.8-6.3]^{\mathrm{a}, \mathrm{c}}$ & $4.9[4.5-5.8]^{\mathrm{b}, \mathrm{c}}$ & $5.2[4.2-6.1]^{\mathrm{b}, \mathrm{c}}$ & 0.0008 \\
\hline
\end{tabular}

Note: Pre = before immersion; Immed. = immediately after immersion; 20 min. = 20 minutes after immersion; 40 min. = 40 minutes after immersion; COP = center-of-pressure; Vel-AP = anteroposterior velocity; Vel-ML = medial-lateral velocity. Different letters represent different groups (Friedman's test, Post-test of Dunn). 


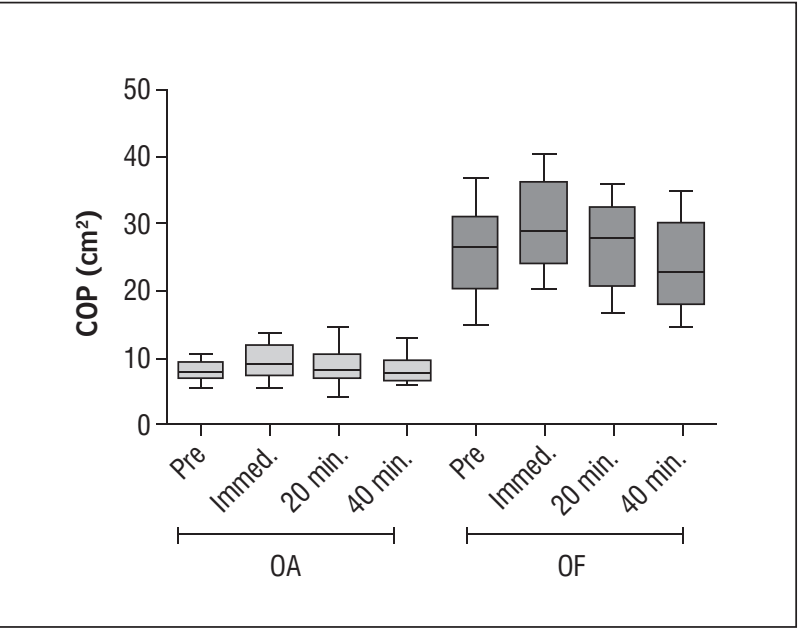

Figure 1 - Comparison of center-of-pressure data (COP/ $\mathrm{cm}^{2}$ ) in different experimental periods in singleleg balance with open eyes (OA) and closed eyes (OF)

Note: Pre = before immersion; Imed. = immediately after immersion; 20 min. $=20$ minutes after immersion; $40 \mathrm{~min} .=40$ minutes after immersion.

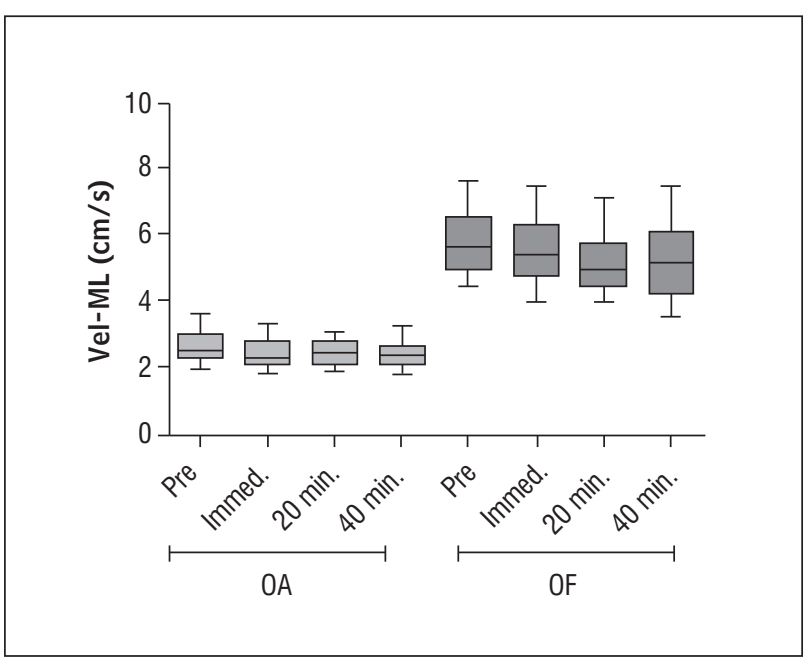

Figure 3 - Medial-lateral velocity (Vel-ML) (cm/s) in different experimental periods in single-leg balance with open eyes (OA) and closed eyes (OF)

Note: Pre = before immersion; Imed. = immediately after immersion; 20 min. = 20 minutes after immersion; $40 \mathrm{~min} .=40$ minutes after immersion.

\section{Discussion}

According to different modalities of cryotherapy application, studies of Herrera et al. (25) report that cold water immersion is the most used to induce

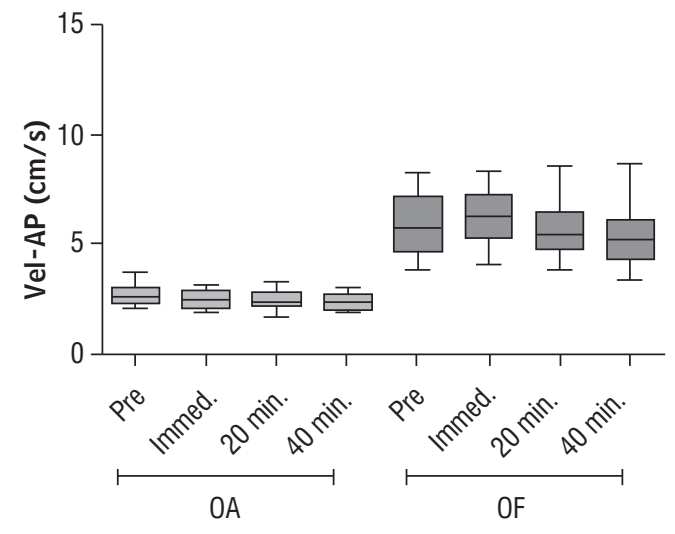

Figure 2 - Anteroposterior velocity (Vel-AP) $(\mathrm{cm} / \mathrm{s})$ in different experimental periods in single-leg balance with open eyes (OA) and closed eyes (OF)

Note: Pre = before immersion; Imed. = immediately after immersion; 20 min. $=20$ minutes after immersion; $40 \mathrm{~min} .=40$ minutes after immersion.

therapeutic effects providing the decrease of Nerve Conduction Velocity (NCV).

The temperature data measured during the four periods of this research (before immersion, immediately, 20 and 40 minutes after cold water immersion) indicate that after 40 minutes of cold water immersion the skin temperature of the ankle did not return to the same temperature values before immersion. These data corroborate with the study of Costello et al. (2) in which they assert that, in all the articles included in their systematic review, the temperature of the skin had not returned to the levels of pre-immersion in the monitoring period of data collection. Through our results, it is possible to affirm that even if the temperature of the skin had not returned to the previous values before cold water immersion, the static balance has not been affected.

Some relevant data showed by Jutte et al. (26) which must be taken into consideration, is the one that says that standardized cold water immersion does not produce the same physiologic results in all patients indicating the necessity of individual adjustments, and it also indicates that the lack of standardized treatments cause different physiologic effects and may express inconsistent results. The present study presented an average temperature of 12.93 ${ }^{\circ} \mathrm{C}( \pm 1.48)$ and variability in the values of cooling in the immediate period after immersion $\left(11.45{ }^{\circ} \mathrm{C}\right.$ to 
$\left.14.41^{\circ} \mathrm{C}\right)$. This variability may occur due to individual characteristics from each subject in the research since some authors $(9,26)$ report that the metabolic activity, body temperature and the individual adipose thickness may interfere in the cooling capacity. This way, it is possible to notice the difficulty regarding to cryotherapy standardize.

Still on the cooling temperature, the study of Chesterton et al. (27) shows that with the tissue cooled in a temperature of $12.5{ }^{\circ} \mathrm{C}$ there might be a decrease of $10 \%$ of NCV. Knight (4) and Uchio et al. (13) affirm that temperatures below $15 \stackrel{\circ}{\circ} \mathrm{C}$ provide fail in NCV. This way, we can affirm that the reached temperature in this study in the immediate after immersion moment $\left(12.93^{\circ} \mathrm{C}\left( \pm 1.48{ }^{\circ} \mathrm{C}\right)\right)$ was enough to produce NCV reduction.

According to Rougier (28) to occur this balance, there is the necessity of control of the center-ofgravity on the support base besides and appropriate command from the CNS for the maintenance of stability through the integration of mechanisms that surround several sensory-neural systems. The author says that when the visual impulses are available, the center-of-pressure and the oscillation area of the COP tend to decrease when compared to CE conditions. Similarly, our data presented a quantitative difference between the $\mathrm{OE}$ and $\mathrm{CE}$ conditions showing reduced values of $\mathrm{COP}$, anteroposterior velocity and medial-lateral velocity, in the eyes open condition when compared to one another. Horak et al. (29) and Mallau et al. (30) report about the visual contribution for the balance and mention that the closed eyes condition decreases the body stability. Studies from Sá and Bim (31) evaluated children with impaired vision and normal vision on the force platform and concluded that the impaired vision interferes in the static and dynamic balance of the children and affirm that therapeutic exercises influenced in the improvement of impaired children.

In this research, it was observed an improvement in the moment after 40 minutes, mainly in CE condition. Despite the present study presents bigger postural oscillations in CE condition, the obtained results in OE condition showed similar results indicating that regardless the presence or absence of visual component there was improvement in the balance parameters.

It was not observed negative influence of cryotherapy in balance in the immediate moment after cold water immersion. No similar researches were found that indicate improvement in balance after cryotherapy of immersion evaluated in the force platform. Studies from Duarte and Freitas (24) and Lund et al. (32) demonstrate that measurements which demand cooperation of the patient, most of the times, present an improvement in the result when repeated in short intervals of time. This way, it is not possible to affirm if the obtained improvement in the present study may have occurred due to learning effect.

Results were found with no significant statistics, such as the case of the research of Cassolato et al. (33) whose reports infer that cryotherapy by immersion has not influenced in the postural control in the static erect posture condition of healthy individuals through the $\mathrm{COP}$ evaluation. With similar results, Hart et al. (34) evaluated the effect of cryotherapy using a plastic bag filled with ice cubes involved by elastic bandage for 20 minutes in the region of the knee so that they could verify the effects of single-leg stance and concluded that alterations were not observed in the ground reaction force parameters.

Still, Jameson et al. (35) affirm that immediately after 20 minutes of treatment with cryotherapy using crushed ice, there was no significant difference in the force of vertical reaction produced during the land, supporting the use of cryotherapy immediately before activities. A study made by Douglas et al. (36) did not observe significant differences in the static balance with fifteen participants evaluated with Biodex. These authors evaluated the balance also in the dynamic condition, which showed significant difference and concluded that fifteen minutes of cryotherapy affect to medial-lateral velocity.

To avoid bias, the present research evaluated healthy individuals only with the male gender, since some researches $(37,38)$ suggest that men and women have different body compositions and different patterns of distribution of adipose tissue, being this one, a temperature insulator (39) usually most found bigger thickness in the female gender (40).

This study evaluated individuals without injuries, therefore effects in individuals with lesions is unknown. The study of Kernozek et al. (17) evaluated fifteen individuals with lateral ankle sprain subjected to 20 minutes of cryotherapy of immersion on singleleg stance on the force platform and had as a result a negative effect in oscillation of Vel-ML after cold water immersion. 


\section{Final considerations}

From the results obtained, we can infer that it was not observed direct interference of cryotherapy of immersion in the variables of postural balance in static situation in the present study. So, the application of cold water immersion as a technique of treatment may be recommended in activities which demand balance in static conditions, however, studies are necessary regards to the effect of cryotherapy in dynamic activities, analyzing its influence on the mechanisms of neuromuscular control and its relation with postural balance.

\section{References}

1. Tomchuk D, Rubley M, Holcomb W, Guadagnoli M, Tarno JM. The Magnitude of tissue cooling during cryotherapy with varied types of compression. J Athl Train. 2010;45(3):230-7.

2. Costello J, McInerney C, Bleakley C, Selfe J, Donnelly A. The use of thermal imaging in assessing skin temperature following cryotherapy : a review. J Therm Biol. 2012;37(2):103-10.

3. Gutierrez-Espinoza H, Lavado-Bustamante I, Méndez-Perez S. Revisión sistemática sobre el efecto analgésico de la crioterapia en el manejo del dolor de origen músculo esquelético. Rev Soc Esp Dolor. 2010;17(5):242-52.

4. Knight KL. Crioterapia no tratamento das lesões esportivas. São Paulo: Manole; 2000.

5. Bleakley CM, O'Connor S, Tully MA, Rocke LG, Macauley DC, McDonough SM. The PRICE study (Protection Rest Ice Compression Elevation): design of a randomised controlled trial comparing standard versus cryokinetic ice applications in the management of acute ankle sprain. BMC Musculoskelet Disord. 2007;8:125.

6. Tremblay F, Estephan L, Legendre M, Sulpher S. Influence of local cooling on proprioceptive acuity in the quadriceps muscle. J Athl Train. 2001;36(2):119-23.

7. Hubbard TJ, Aronson SL, Denegar CR. Does Cryotherapy hasten return to participation? A systematic review. J Athl Train. 2004;39(1):88-94.
8. Khanmohammadi R, Someh M, Ghafarinejad F. The effect of cryotherapy on the normal ankle joint position sense. Asian J Sports Med. 2011;2(2):91-8.

9. Merrick MA, Jutte LS, Smith ME. Cold modalilities with different thermodynamic properties produce different surface and intramuscular temperatures. J Athl Train. 2003;38(1):28-33.

10. Algafly AA, George KP. The effect of cryotherapy on nerve conduction velocity, pain threshold and pain tolerance. Br J Sports Med. 2007;41(6):365-9.

11. Thieme HA, Ingersoll CD, Knight KL, Ozmun JC. Cooling does not affect knee proprioception. J Athl Train. 1996;31(1):8-11.

12. Surenkok O, Aytar A, Akman MN. Cryotherapy impairs knee joint position sense and balance. Isokinet Exerc Sci. 2008;16(1):69-73.

13. Uchio Y, Ochi M, Fujihara A, Adachi N, Iwasa J, Sakai Y. Cryotherapy influences joint laxity and position sense of the healthy knee joint. Arch Phys Med Rehabil. 2003;84(1):131-5.

14. Schmid S, Moffat M, Gutierrez GM. Effect of knee joint cooling on the electromyographic activity of lower extremity muscles during a plyometric exercise. J Electromyogr Kinesiol. 2010;20(6):1075-81.

15. Cabral AS, Corea BS, Igarashi Y. Efeito da aplicação do frio na sensação de posicionamento articular do tornozelo. Rev Para Med. 2010;24(2):23-8.

16. Wassinger CA, Myers JB, Gatti JM, Conley KM, Lephart SM. Proprioception and throwing accuracy in the dominant shoulder after cryotherapy. J Athl Train. 2007;42(1):84-9.

17. Kernozek TW, Greany JF, Anderson DR, Heel VAN, Youngdahl RL, Benesh BG, et al. The effect of immersion cryotherapy on medial-lateral postural sway variability in individuals with a lateral ankle sprain. Physiother Res Int. 2008;13(2):107-18.

18. Baldaço FO, Cadó VP, de Souza J, Mota CB, Lemos JC. Análise do treinamento proprioceptivo no equilíbrio de atletas de futsal feminino. Fisioter Mov. 2010;23(2):183-92.

19. Massion J. Postural control system. Curr Opin Neurobiol. 1994;4(6):877-87. 
20. Horak FB. Postural orientation and equilibrium : what do we need to know about neural control of balance to prevent falls? Age Ageing. 2006;35(Suppl 2):ii7-ii11.

21. Weimar W, Campbell B. The influence of ankle cryotherapy on unilateral balance. Med Sci Sport Exerc. 2004;36(5):S187.

22. da Silva RA, Bilodeau M, Parreira RB, Teixeira DC, Amorim CF. Age-related differences in time-limit performance and force platform-based balance measures during one-leg stance. J Electromyogr Kinesiol. 2013;23(3):634-9.

23. Moreira A, Okano AH, Ronque ERV, Souza M, Oliveira PR. Reprodutibilidade dos testes de salto vertical e salto horizontal triplo consecutivo em diferentes etapas da preparação de basquetebolistas de alto rendimento. Rev Bras Cineantropom Desemp Hum. 2006;8(4):66-72.

24. Duarte M, Freitas SMSF. Revisão sobre posturografia baseada em plataforma de força para avaliação do equilíbrio. Rev Bras Fisioter. 2010;14(3):183-92.

25. Herrera E, Sandoval MC, Camargo DM, Salvini TF. Motor and sensory nerve conduction are affected differently by ice pack, ice massage, and cold water immersion. Phys Ther. 2010;90(4):581-91.

26. Jutte LS, Hawkins J, Miller KC, Long BC, Knight KL. Skinfold thickness at 8 common cryotherapy sites in various athletic populations. J Athl Train. 2012; 47(2):170-7.

27. Chesterton LS, Foster NE, Ross L. Skin temperature response to cryotherapy. Arch Phys Med Reabil. 2002;83(4):543-9.

28. Rougier P. The influence of having the eyelids open or closed on undisturbed postural control. Neurosci Res. 2003;47(1):73-83.

29. Horak FB, Nashner LM, Diener HC. Postural strategies associated with somatosensory and vestibular loss. Exp Brain Res. 1990;82(1):167-77.

30. Mallau S, Vaugoyeau M, Assaiante C. Postural strategies and sensory integration: no turning point between childhood and adolescence. PLoS One. 2010; 5(9):e13078.

31. de Sá CG, Bim CR. Análise estabilométrica pré e pósexercícios fisioterapêuticos em crianças deficientes visuais. Fisioter Mov. 2012;25(4):811-9.
32. Lund H, Søndergaard K, Zachariassen T, Christensen R, Bülow P, Henriksen M, et al. Learning effect of isokinetic measurements in healthy subjects, and reliability and comparability of Biodex and Lido dynamometers. Clin Physiol Funct Imaging. 2005;25(2):75-82.

33. Cassolato KM, Artifon EL, Evans A, Bonfim DO, Cristina J. Influência da crioterapia no controle postural da postura ereta em indivíduos saudáveis. Rev Bras Clin Med. 2012;10(5):402-6.

34. Hart JM, Leonard JL, Ingersoll CD. Single-leg landing strategy after knee-joint cryotherapy. J Sport Rehabil. 2005;14(4):313-20.

35. Jameson AG, Kinzey SJ, Hallam JS. Lower-extremityjoint cryotherapy does not affect vertical ground-reaction forces during landing. J Sport Rehabil. 2001; $10(2): 132-42$.

36. Douglas M, Bivens S, Pesterfield J, Clemson N, Castle W, Sole G, et al. Immediate effects of cryotherapy on static and dynamic balance. Int J Sport Phys Ther. 2013;8(1):9-14.

37. Otte JW, Merrick MA, Ingersoll CD, Cordova ML. Subcutaneous Adipose tissue thickness cooling time during cryotherapy. Arch Phys Med Rehabil. 2002; 83(11):1501-5.

38. Jutte LS, Merrick MA, Ingersoll CD, Edwards JE. The relationship between intramuscular temperature, skin temperature, and adipose thickness during cryotherapy and rewarming. Arch Phys Med Rehabil. 2001;82(6):845-50.

39. Kennet J, Hardaker N, Hobbs S, Selfe J. Cooling efficiency of 4 common Cryotherapeutic Agents. J Athl Train. 2007;42(3):343-8.

40. Yanagisawa 0, Fukubayashi T. Diffusion-weighted magnetic resonance imaging reveals the effects of different cooling temperatures on the diffusion of water molecules and perfusion within human skeletal muscle. Clin Radiol. 2010;65(11):874-80.

Received: 05/09/2014 Recebido: 09/05/2014

Approved: 04/06/2015 Aprovado: 06/04/2015 
